УАK $11 / 12$

ББК 87.21

DOI 10.22394/1682-2358-2019-5-96-102

E.V. Bagrova, Candidate of Sciences (Pbilosophy), lecturer of the Applied Mathematics and Natural Sciences Department, Noyabrsk Institute of Oil and Gas, Branch of Tyumen Industrial University

\section{CHARACTERISTICS \\ OF CRISIS \\ AS AN INTEGRAL \\ ELEMENT \\ OF THE STRUCTURE OF SOCIAL BEING}

Various existing theories of social being, individual concepts affecting social elements are analyzed. Significant attention is paid to the processes of worldview transformation in crisis phenomena. As a result, the crisis is defined as a means of changing social being and its philosophical understanding, as well as the worldview transformation of most individuals.

Key words and word-combinations: social being, transformation, crisis.
E.B. Багрова, кандидат философских наук, преподаватель кафедри прикладной математики и естественнонаучных дисииплин Ноябрьского института нефти и газа (филиала) Тюменского индустриального университета (email:bagrova.e.»mail.ru)

\section{ХАРАКТЕРИСТИКА КРИЗИСА КАК НЕОТЬЕМАЕМОГО ЭАЕМЕНТА СТРУКТУРЫ СОЦИААЬНОГО БЫТИЯ}

\begin{abstract}
Аннотация. Проведен анализ различных теорий социального бытия и отдельных концепций, затрагивающих элементы общества. Существенное внимание уделяется процессам трансформации мировоззрения в кризисных явлениях. Кризис определяется автором как средство изменения социального бытия и его философского осмысления, а также трансформации мировоззрения большинства индивидов.
\end{abstract}

Ключевые слова и словосочетания: социальное бытие, трансформация, кризис.

K явАяются его важной составцяющей и происходят и в отАельных отраслях, и в целых системах. Иногда они охватывают группы стран и Ааже континенты. Причины кризисов могут быть разАичными и находиться в разных сферах - экономической, политической, социамьной. Управление кризисами - неотьеммемая часть соџиамьного управления, Аля эффективной реацизации которого необходимо глубокое понимание природы кризисных явмений. Аанная статья направлена на решение именно этой задачи. 
Бытие представляет собой сложное фимософское понятие и не имеет оАнозначного определения. В наиболее общем смысле бытие разграничивается на космос, природу и человека [1]. На основе географической истории развития планеты можно утверждать, что кризисы составмяют опредеменное свойство природы. По сути, кризисы дмя природы - это принџипиальное изменение состояний или же доминирующих сил развития. Можно предпомагать, что кризисами природы были цедниковые периоды, формировавшие принципиально иные условия бытия, в результате чего многие виды, такие как динозавры, вымерли [2]. Аналогичные события, в частности взрывы звезА, наблюдаются в космосе. Все эти явления характеризуются существенными изменениями первоначального состояния бытия дмя его части, включая живые и неживые объекты. Чаще всего они затрагивают сразу несколько пластов природы или космоса, а также могут повлиять на спеџифику соединения размичных элементов бытия в единую систему. Схожие явмения и проџессы происходят с человеком в соџиальном пласте бытия. Характеристика кризисов как неотъемлемых элементов соџиального бытия, обоснование их роли в развитии и трансформации природы и общества в качестве взаимосвязанных систем явмяются главной целью данной статьи.

Соџиальный пласт бытия отличается от природы и космоса более глубоким уровнем изученности различными соџиальными науками, в том числе философией. Кроме того, он обцадает высокой степенью изменчивости в обозримом временном промежутке [3, с. 689], а также разнородности за счет представменности различными обществами и цивицизаџиями.

С позищии изучения сощиального пласта бытия в контексте кризисов он обладает следующим набором особенностей:

- соџиальное бытие включает в себя множество индивидов, каждый из которых действует независимо, обладая џемями и стремлениями, одновременно являясь частью соџиума, что накладывает ряд ограничений на его действия. Ааже в случае, если индивид противоречит обшеству, нарушая его законы, он учитывает их в своем поведении [4, с. 486-488];

- соџиальное бытие включает в себя различные плоскости, которые частично пересекаются в каждый конкретный момент, однако их пересечения подвержены изменениям в ходе развития общества [5]. Так, очевидно пересечение социальной и экономической сфер его развития. Тем не менее эти две плоскости бытия совершенно по-разному взаимосвязаны в различных странах, а также изменяются с течением времени. К примеру, специфика их пересечения во многом зависит от доминирующей политической парадигмы в обществе, детерминируюшей приоритетность капиталистических или соџиальных ценностей [6] ;

- социальные пмоскости, формирующие бытие, обладают также свойством внутренней изменчивости. К примеру, сощиальное равенство как фимософская категория детерминирует развитие нескольких эмементов бытия, но отметим принџипиальное размичие понимания данного термина в начале и в конџе XX в.;

- человек, являясь частью соџиального бытия, постоянно предпринимает 
попытки его разнопланового осмысления, нередко получая противоречивые результаты. Философская рефлексия меняет принџипы взаимодействия индивидов с социальным бытием и в конечном счете - само бытие.

Исходя из перечисленных особенностей, можно утвержАать, что существенная часть кризисов соџиального бытия имеет антропогенный характер. Кризисы, имеющие иной характер по своей первопричине, в большей степени присущи природе и космосу. В российской науке в силу ее методологии социальное бытие как феномен определяется нейтрацьно. В западной науке социальное бытие нередко детерминируется вектором улучшения качества жизни. ЗАесь чаще используется термин, отражающий зАоровое качество бытия, что вкАючает в себя внутренние и внешние проџессы, взаимодействие индивидов и соџиума [7]. В такой постановке вопроса здоровое развитие или состояние бытия предполагается в качестве некоторого недостижимого идеала, требующего наиболее полной характеристики. Принципиальные отклонения как в динамике, так и в статике социального бытия от зАорового состояния характеризуются как кризис. Аیя мучшего понимания кризисных состояний представим несколько кАючевых тезисов, описывающих индивидов в ЗАоровом состоянии соџиального бытия:

- принятие себя и окружающей действительности;

- забота об экологической безопасности;

- позитивное отношение к окружающей действительности, вкАючая размичные эмементы бытия;

- наличие целей в жизни, которые, с одной стороны, Аолжны согласовываться с остальными принџипами, а с Аругой - быть Аостаточно индивидуальными;

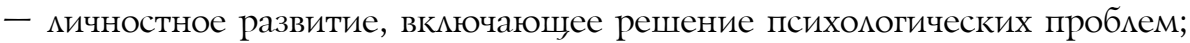

- автономность, подразумевающую независимость человека от общества, в частности, отсутствие склонности подАаваться эффекту толпы, а также психологическую стабильность.

Таким образом, индивиды в зАоровом соџиальном состоянии склонны к заботе о себе и окружающих, наџелены на сохранение и развитие социокультурНой среАЫ. ПоАобный поАхоА во многом СОотносится с иАеями устойчивого развития [8, с. 305] при условии, что поА кризисом подразумевается все то, что может вывести индивидов из состояния стабильности. Поскольку соџиальное бытие преАставляет собой сложный и многогранный феномен, кризисы могут затрагивать различные сферы, от индивидуальной, психологической, Ао соџиальной и экономической во всем многообразии их проявления. При этом основной причиной кризисов соџиального бытия второй половины XX - начала XXI в. научным сообществом признается финансовая составцяющая [9] .

Преобладание финансовых кризисов наА другими детерминировано нескоцькими причинами. Первой из них явцяется развитие общества массового потребцения, которое в своих крайних формах оџенивает все остацьные грани бытия, связанного с финансовой компонентой. Финансы становятся превамирующим инструментом оџенки социального бытия [10, с. 1025-1030]. 
Второй причиной является высокий уровень закредитованности населения и его значительная зависимость от притока денежных средств, а также детерминированность соџиального статуса фискацьной составцяющей. В результате изменилось само восприятие денег. Так, изначально деньги, являвшиеся

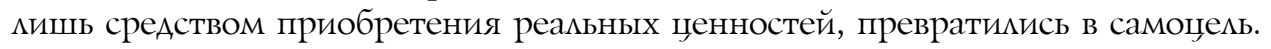
Произошла так называемая финансификация социального бытия, которая заключается в существенном преобладании денежной массы наА реальными создаваемыми благами [11, с. 1672]. При этом сами блага обесцениваются непосреАственно в персональной системе ценностей индивидов. В связи с названными причинами большинство последних кризисов соџиацьного бытия так или иначе связаны с финансовой составцяющей.

Несмотря на смену детерминант кризисов соџиального бытия, а также их концентрации в экономической сфере, их общий механизм можно структурировать следующим образом:

1. Относительно устойчивое состояние соџиального бытия, детерминированное набором определенных элементов и философских парадигм, их характеризующих, воспринимается обществом как здоровое, или «естественное».

2. Появление отдельных незначительных отклонений, которые в математическом смысле не превышают 5\%, а в философском отношении не подАаются систематизации каким-либо образом, за искмючением пласта социального бытия. Такие аномации могут затрагивать сразу несколько пластов соџиального бытия ици множественно появцяться в разцичных пластах. Часто подобные аномалии связаны с Авумя ключевыми инициативами. Первой из них является появление мюдей, несогласных с Аоминирующей парадигмой мышления, кАючевыми постулатами основных философских идей, детерминирующих социальную, политическую и экономическую сферы общества [12, с. 230-232] . Второй инициативой явцяется мотивация к повышению мичного благосостояния за счет использования недостатков существующей системы. Аанная инициатива, вне зависимости от того, какие именно недостатки используются, приводит к разрушению изнутри существующей системы и в конечном счете к еe краху [13, с. 300-302].

3. Усимение отклонений до заметного, а затем и до существенного уровня. Некоторые тенденции, появившиеся на втором этапе, усиливаются, в том числе за счет кумумятивного эффекта и вовлеченности разцичных плоскостей сощиального развития, а иные затухают или же остаются в стагнирующем состоянии долгое время, не участвуя в кризисных явлениях.

4. Усилившиеся тенденџии формируют существенные соџиальные противоречия, дисбалансы и финансовые провалы, в результате чего действующая система перестает функционировать Аолжным образом. По сути, речь идет о полной или частичной Аисфункции существовавшей ранее системы социального бытия. Именно в этой точке, чаще всего называемой кризисом, начинается формирование потребностей большинства индивидов к социальным и мичностным изменениям или же к аАаптации к сложившейся ситуации [14] .

5. Происходят множкественные изменения соединений эмементов социального бытия, затрагивающие как фактический уровень, так и понимание 
и осознание реальных изменений индивидами. По сути, вначале происходят изменения в мировоззрении значимой части индивидов, что меняет соџиальные проџессы. В результате всем индивидам приходится адаптироваться к новому состоянию бытия. При этом их можно разделить на три группы. Первая группа мегко адаптируется, и качество ее контакта с соџиацыным бытием возрастает. Вторая группа адаптируется крайне слабо, что существенно ухудшает качество контакта с социальным бытием. Третья группа адаптируется в некоторой мере, оставаясь на среднем уровне. Отметим, что при каждом значимом изменении социального бытия индивиды имеют шансы попасть в мюбую из трех названных групп в зависимости от их индивидуацьных особенностей и ценностей, а также соответствия их внутренних представлений новым внешним условиям [15, с. 730]. При этом, чем более близки индивиды к описанным, соответствующим зАоровому состоянию социального бытия, тем проще им адаптироваться к изменившимся условиям. Тем не менее одним из аспектов кризиса соџиального бытия явцяется утрата индивидами контакта со своей «зАоровой» частью, что приводит к формированию множественных конфликтов и противоречий с окружающим миром. Именно поэтому во время кризисов всегда существуют группы мюдей, резко не принимающих соџиальные изменения.

6. Общество стабилизируется на новом уровне социального бытия, которое считается нормальным, или зАоровым.

Механизм кризисов явцяется цикцическим, и после шестого этапа вновь происходит переход к первому. Тем не менее в результате каждого нового витка, помимо очевидных изменений на событийном и социальном уровнях, происходят изменения в индивидуацьном мировоззрении, которые описываются моделью Аиффузии инноваций (рисунок) [16, с. 200-205] .

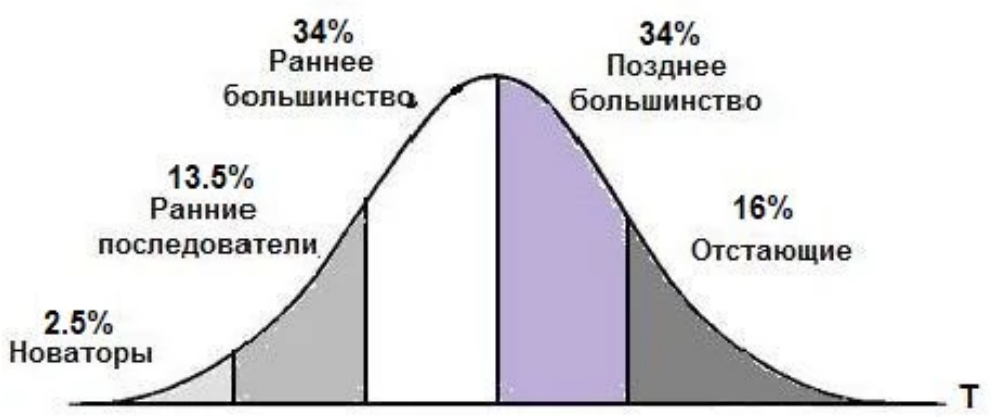

Модель дифФузии инноваџий и распространения изменений в мировоззрении

На втором этапе описанного механизма развития кризиса социального бытия происходит формирование группы новаторов, объединенных общностью идей. Аля реализации проявлений кризиса Аанное мировоззрение долэкно разделяться существенной группой, а именно ранними последоватемями. Эти 
Аве группы создают Аостаточный уровень вовлечения индивидов в обновления Аоминирующих мировоззренческих конщепџий в соџиальном бытии. Три выделенные Аля пятого этапа группы соответственно преАставцяют собой раннее большинство, отстающих и позАнее большинство. Следовательно, около $16 \%$ населения не примут происходящие изменения соџиального бытия вне зависимости от их фактической специфики. Представленная концепџия дополняется сетевым принципом, объясняющим, как именно происходит распространение нового мировоззрения, передача его от одного индивида к Аругому - путем прямого общения или же опосредованного через систему социальных действий $[17$, с. 100-103] .

Таким образом, кризис играет совершенно особую роль в социальном бытии. По сути, он явмяется среАством его трансформаџии, а также соответствующих изменений в мировоззрении. При этом изменения в философском осмыслении мира небольшой группы активных индивидов явцяются первопричинами кризиса, в то время как большинство знакомится с обновленными концепџиями, интегрируя их как элементы социального бытия в свою повседневную жизнь. Следует отметить, что прошиые кризисы формируют новые преАставления о социальном бытии таким образом, что их результаты на данный момент воспринимаются как норма. Приведем два разноплановых примера. Так, после Второй мировой войны произошел кризис ценностей, в результате актуацизировалось такое направление философской мысли, как гуманизм, а человек стал важной фигурой всех социальных наук и концепџий. В современной западной философии доминирует концепция здорового бытия, сформированная в ходе кризиса [18, с. 361-363]. Все обыденные ценностные феномены современности, включающие толерантность и равноправие, являются Аовольно новыми мировоззренческими концепџиями, сформированными 50-60 мет назаА. Схожая ситуация касается и мирового финансового кризиса 2008 г., когда бымо выявмено, что бесконечное мультипиицирование банковских финансовых инструментов фактически разрушает финансовую систему, в результате чего уровень ее надежности деградирует до крайне низкого. После этого кризиса требования к банковским инструментам и разцичным ценным бумагам возросли, а более рискованные участники финансового рынка переключились на принципиально иные инструменты, например криптовалюты $[19$, c. $343-345]$.

Таким образом, многие современные мировоззренческие постулаты, связанные со здоровым состоянием бытия, были сформированы в проџессе преАыАущих кризисов. При этом, поскольку скорость Аиффузии мировоззрения во время кризисов существенно увеличивается, эти постулаты становятся частью социального бытия в сжатые сроки. Именно подобным обновлением мировоззрения в краткие сроки, затрагивающим большинство индивидов и пластов социального бытия, характеризуется кризис, который представцяет собой средство изменения социального бытия и его философского осмысления, что обусловцивает неотъемлемость кризиса от структуры социального бытия и характеризует его роль в соџиальной организаџии. 


\section{Библиографический список}

1. Абишев К.А. Мышление и бытие // Вопросы философии. 2014. №. 3. С. 62-72.

2. Шиловская Н.С. Человек как субъект, бытие и бытие субъекта в истории и современности // Философская мысль. 2012. №. 1. С. 171-203.

3. Davidson R. J., McEwen B. S. Social influences on neuroplasticity: stress and interventions to promote well-being // Nature neuroscience. 2012. T. 15, №. 5.

4. Turner T. S. The social skin // HAU: Journal of Ethnographic Theory. 2012. T. 2, № 2. C. 486-504.

5. Багрова E.B. Кризисные явления в общественном развитии и управление ими. Новый философский подход // Философская мысль. 2016. № 12. С. 93-104.

6. Krugman P. Crises: The price of globalisation? // Economics of Globalisation. Routledge, 2017. C. 31-50.

7. Goswami H. Social relationships and children's subjective well-being // Social Indicators Research. 2012. T. 107, № 3. C. 575-588.

8. Griggs D. [et al.]. Policy: Sustainable development goals for people and planet // Nature. 2013. T. 495, № 7441 .

9. Ingham A.G. From public issue to personal trouble: Well-being and the fiscal crisis of the state // Sociology of Sport Journal. 1985. T. 2, № 1. C. 43-55.

10. Gallagher M.W., Lopez S.J., Preacher K.J. The hierarchical structure of well-being // Journal of personality. 2009. T. 77, № 4. C. 1025-1050.

11. Morcos A.S., Harvey C.D. History-dependent variability in population dynamics during evidence accumulation in cortex // Nature neuroscience. 2016. T. 19, № 12.

12. Joeger M.M., Holm A. Conformists or rebels? Relative risk aversion, educational decisions and social class reproduction // Rationality and Society. 2012. T. 24, № 2. C. 221-253.

13. Clerck-Sachsse J. De. Civil society and democracy in the EU: The paradox of the European citizens' initiative // Perspectives on European Politics and Society. 2012. T. 13, № 3. C. 299-311.

14. Dixon T. «Emotion»: The history of a keyword in crisis // Emotion Review. 2012. T. 4, № 4. C. $338-344$.

15. Veit C.T., Ware J.E. The structure of psychological distress and well-being in general populations //Journal of consulting and clinical psychology. 1983. T. 51, № 5.

16. Autant-Bernard C., Fadairo M., Massard N. Knowledge diffusion and innovation policies within the European regions: Challenges based on recent empirical evidence // Research Policy. 2013. T. 42, №. 1. C. 196-210.

17. Cho Y., Hwang J., Lee D. Identification of effective opinion leaders in the diffusion of technological innovation: A social network approach // Technological Forecasting and Social Change. 2012. T. 79, № 1. C. 97-106.

18. Chakravartty P., Da Silva D.F. Accumulation, dispossession, and debt: The racial logic of global capitalism - an introduction // American Quarterly. 2012. T. 64, № 3. C. 361-385.

19. Fry J., Cheah E.T. Negative bubbles and shocks in cryptocurrency markets // International Review of Financial Analysis. 2016. T. 47. C. 343-352. 